http://dx.doi.org/10.4314/jae.v16i2.15

\title{
Knowledge, Perception and Adaptation Strategies to Climate Change among Farmers in Southern Agricultural Zone of Nasarawa State, Nigeria
}

\author{
Salau, E. S.; Onuk, E. G. and Ibrahim, A. \\ Department of Agricultural Economics and Extension \\ Nasarawa State University, Keffi. \\ Corresponding e-mail emmasalau@yahoo.com
}

\begin{abstract}
Climate change is perhaps the most serious environmental threat facing mankind worldwide. The study was designed to assess the knowledge, perception and adaptation strategies to climate change among farmers in southern agricultural zone of Nasarawa state. The specific objectives were to: identify the sources of information on climate change by respondents; assess their knowledge and perception of climate change phenomenon; identify adaptation strategies used and the factors militating against their adaptive capacity. A multi-stage sampling procedure was used to select a total of 150 respondents from the zone for the study. Data collection was through an interview schedule. Simple descriptive statistics such as frequency, percentage and mean scores were used to achieve the objectives. The null hypothesis was tested using a multiple regression model. The mean age of the respondents was 48 years. Majority (89.33\%) of them were males while their average farming experience was 27 years. Most (38\%) of the farmers in the area had no formal education and majority (76.7\%) of them used inherited farmlands. Annual income level of the respondents was encouraging with a mean of N326, 461.30 per annum. Most (68\%) of them relied on radio as their major source of information on climate change. The perceived indicators of climate change included excessive high temperatures, low and irregular rainfall pattern and low crop yields among others. Adaptation strategies used by the respondents included agro-forestry practices, crop diversification, use of organic manures, planting of early maturing and disease/drought resistant varieties. The major constraints to adaptation by the respondents were inadequate finance, poor infrastructures, unfavourable government/trade policies and poor technology. It was recommended that adult education programmes should be strengthened in the area to reduce illiteracy among farmers. Extension agents in the area should incorporate climate change information in their extension messages while government should intensify efforts in the area of integrated rural development.
\end{abstract}


Key words: Knowledge, Perception, Adaptation Strategies, Climate Change, Farmers, Southern Agricultural Zone of Nasarawa State.

\section{Introduction}

Climate change is a worldwide phenomenon that has impacted negatively on the livelihood systems of the entire human race. The climate is said to have changed if there is a sustained change in the behaviour of weather elements like rainfall, temperature and relative humidity (Shrotriya and Prakash, 2010). Climate change refers to any change in the climate overtime, whether due to natural variability or as a result of human activity. It can also be attributed directly or indirectly to human activities that alter the composition of the global atmosphere and which are in addition to natural variability observed over comparable time periods (Intergovernmental Panel on Climate Change, IPCC, 2001, 2007).

Studies have shown that agriculture is both a culprit and victim of climate change. Culprit in the sense that Green House Gas (GHG) emissions from food and the agricultural sector account for about $18 \%$ of global green house gas emission; deforestation also accounts for $18 \%$ carbon dioxide emissions. The world's 130 million ha of rice paddies are estimated to produce 50-100 million metric tonnes of methane annually. High emission of green house gases accelerates the rate of global warming and the rapid depletion of the ozone layer. Agriculture is also the worst victim of climate change due to its vulnerability to extreme weather events. This is more pronounced in climes where agriculture still remains the main source of livelihood, especially in developing countries like Nigeria. This has exacerbated poverty and has become a major albatross to the attainment of the Millennium Development Goal of reducing poverty and hunger by half by the year 2015 (Agwu et al. 2010; Shrotriya; Prakash, 2010).

Climate change has greater negative impacts on poorer farm households as they have the lowest capacity to adapt to changes in climatic conditions hence, the need for them to device some daptation measures to cope with extreme weather conditions (Adger et al 2003). According to IPCC (2001), adaptations are adjustments or interventions, which take place in order to manage the losses or take advantage of the opportunities presented by a changing climate. Studies of farm level adoption of adaptation strategies are important to provide information that can be used to formulate policies that will enhance adaptation as a tool for managing a variety of risks associated with climate change in agriculture. Examples of such adaptation options include: crop diversification, mixed croplivestock farming systems, using different crop varieties, changing planting and harvesting dates, and mixing less productive, drought-resistant varieties and highyield water sensitive crops (Bradshaw et al.2004). However, farmers' adaptive capacity to climate change is undermined by several factors that range from limited understanding of the nature and consequences of climate change, farm members' health status, unemployment that is supposed to be both complement and supplement in agricultural incomes, and poor rural infrastructure (Edwards and Clark, 2001). 


\section{Problem statement}

Small scale farmers, who constitute the bulk of the poor in Africa, face prospects of tragic crop failures, reduced agricultural productivity, increased hunger, malnutrition and diseases as a result of climate change (Zoellick, 2009). It is projected that crop yield in Africa may fall by $10-20 \%$ by the year 2050 or even up to $50 \%$ due to climate change (Jones, 2003). Countries in Sub-Saharan Africa, including Nigeria, are likely to suffer the most because of their geographical location, low incomes, and low institutional capacity, as well as their greater reliance on climate-sensitive renewable natural resources sectors like agriculture. Given the high level of illiteracy among rural farmers in Nasarawa state coupled with the poor nature of the public extension service, it is not known if these farmers have access to adequate information on climate change events and their impacts on agriculture. It is also not certain what coping strategies (adaptation measures) have been evolved by the farmers to ensure sustainable production. Their low income status and absence of viable support system may further worsen the impacts of climate change on their livelihood system. This study was therefore designed to assess the knowledge/perception and adaptation strategies to climate change by farmers in the southern agricultural zone of Nasarawa state.

\section{Objectives of the study}

The general objective of the study was to assess the knowledge, perception and adaptation strategies to climate change among farmers in southern agricultural zone of Nasarawa State. The specific objectives were to:

(i) identify the sources of information on climate change used by respondents;

(ii) determine the level of knowledge of the respondents about climate change phenomena;

(iii) identify the adaptation measures used to cope with climate change, and;

(iv) identify the problems encountered by the respondents in adapting to climate change effects.

\section{Hypothesis}

Ho: Farmers' socio-economic characteristics have no significant influence on their level of adaptation to climate change.

\section{Methodology}

This study was conducted in the southern agricultural zone of Nasarawa state north central Nigeria. It is one of the three agricultural zones in the state with headquarters at Obi. The southern zone covers 5 LGAs including Awe, Doma, Keana, Lafia and Obi LGAs. A multistage sampling procedure was adopted in this study. Firstly, 3 LGAs were randomly selected out of 5 LGAs in the zone. 
Secondly, five farming communities (villages) were randomly selected from each of the 3 selected LGAs to give 15 villages. In the third stage ten (10) farmers were randomly selected from each of the 15 villages to give 150 respondents for the study. Primary data were collected through a structured interview schedule administered on respondents. The instrument captured questions related to all the objectives of the study.

Data analysis was done using the statistical package for social sciences (SPSS) 15 version. Simple descriptive statistics like frequency, percentage, mean and standard deviation were used to satisfy objectives 1, 2 and 3. A 3-point Likert type scale was used to satisfy objective 4 . The scale has response options such as: Very serious $=3$, Serious $=2$ and Not serious $=1$. The values were summed up to obtain 6 and divided by 3 to get a mean of 2 . Any factor whose mean score is equal to/greater than 2 was considered a serious constraint while factors whose mean scores were less than 2 were considered not serious constraints. A multiple regression model was used to test the hypothesis. The explicit form of the model is given as: $Y=a+b_{1} x_{1}+b_{2} x_{2}+b_{3} x_{3}+b_{4} x_{4}+b_{5} x_{5}+b_{6} x_{6}+b_{7} x_{7}=u$

Where: $\mathrm{Y}=$ Adaptation index (No. of adaptation measures used)

$$
\begin{aligned}
& a=\text { constant } \\
& b_{1}-b_{7}=\text { regression coefficients } \\
& x_{1}=\text { age of respondent in years } \\
& x_{2}=\text { Gender (male }=1, \text { female }=2 \text { ) } \\
& x_{3}=\text { Years of farming experience (years) } \\
& x_{4}=\text { Farm size (hectare) } \\
& x_{5}=\text { Level of formal education (years of schooling) } \\
& x_{6}=\text { Annual income (in naira) } \\
& x_{7}=\text { Extension contacts (Number of visits per year). } \\
& x_{8}=\text { Household size } \\
& x_{9}=\text { Number of social organizations belonged } \\
& x_{10}=\text { Amount of credit received during the past 5years (in naira) } \\
& x_{11}=\text { Type of land tenure system used }
\end{aligned}
$$

\section{Results and Discussion}

\section{Socioeconomic characteristics of respondents}

Table1 shows the socioeconomic characteristics of the respondents as follows: Most $(36.7 \%)$ of the respondents were aged between $41-50$ years with a mean age of 48 years. This shows that farmers in the study area were mostly middle 
aged people who are still strong and energetic and are most likely to adopt more techniques to cope with climate change events. Majority $(89.33 \%)$ of the respondents were males with only $10.67 \%$ as females. The mean years of farming experience of the respondents was 27 years. This implies that most of the farmers in the area were not new entrants in the occupation. They must have had significant experience in climate change phenomenon and must have evolved various adaptation strategies to cope with the impacts. A greater proportion (38\%) of the respondents had no formal education, $36.67 \%$ had primary education, $16 \%$ had secondary education while $9.33 \%$ attained tertiary education. This shows that farmers in the area were mostly illiterates. This low level of education is capable of limiting their access to accurate information on climate change and hence their adaptive capacity might be very low. The mean farm size of the respondents was $3.5 \mathrm{ha}$. This shows a preponderance of small scale farmers in the study area. Small scale farmers generally have inadequate capital to adopt technologies that require huge capital. This will likely affect their adaptive capacity to climate change. The mean household size of the respondents was 14 . This implies that most of the respondents had small household sizes.

Table 1 also shows that the mean number of extension visits per year was 29 . This implies that farmers in the zone had an average of two extension visits per month which is in line with recommended visit schedules of village extension agents under the $T$ \& $V$ system. Frequent extension contact enhances rapid dissemination of recommended practices and increases the adoption capacity of the farmers. Majority (50\%) of the respondents belonged to one or two social organizations, $34.67 \%$ did not belong to any social organization while $14.67 \%$ had between $3-4$ organizations. This implies that most of the farmers participated in social organizations. This will provide avenue for information sharing thereby enhancing adoption capacity. The mean annual income was N326, 461.00. This implies that farmers in the study area were mainly low income earners. Majority (73.35\%) of the respondents did not use any credit facility during the past five years. Only $18.67 \%$ received between N1000 - N500, 000 as credit. Majority $(76.67 \%)$ of the respondents inherited their farm lands while $11.33 \%$ used community land. 
TABLE 1

Distribution of respondents according to their socioeconomic characteristics $n=150$

\begin{tabular}{|c|c|c|c|}
\hline \multirow{2}{*}{$\begin{array}{l}\text { Variable } \\
\text { Aqe }\end{array}$} & \multirow[t]{2}{*}{ Frequency } & \multicolumn{2}{|c|}{ Percentage Mean } \\
\hline & & & \\
\hline Below 21 & 1 & 0.67 & \\
\hline $21-30$ & 5 & 3.33 & \\
\hline $31-40$ & 43 & 28.67 & 48 years \\
\hline $41-50$ & 55 & 36.67 & \\
\hline $51-60$ & 23 & 15.33 & \\
\hline Above 60 & 23 & 15.33 & \\
\hline \multicolumn{4}{|l|}{ Gender } \\
\hline Male & 134 & 89.33 & \\
\hline Female & 16 & 10.67 & \\
\hline \multicolumn{4}{|l|}{ Years of farming experience } \\
\hline $1-10$ years & 12 & 8.00 & \\
\hline $11-20$ years & 42 & 28.00 & \\
\hline $21-30$ years & 51 & 34.00 & 27 years \\
\hline $31-40$ years & 31 & 20.00 & \\
\hline \multirow{2}{*}{\multicolumn{4}{|c|}{ Level of education }} \\
\hline & & & \\
\hline None & 57 & 38.00 & \\
\hline Primary & 55 & 36.67 & \\
\hline Secondary & 24 & 16.00 & \\
\hline Tertiary & 14 & 9.33 & \\
\hline \multicolumn{4}{|l|}{ Farm size (ha) } \\
\hline $1-5$ ha & 62 & 41.33 & \\
\hline 6-10ha & 50 & 33.33 & 3.5 ha. \\
\hline \multicolumn{4}{|l|}{ Household size } \\
\hline $1-10$ & 81 & 54.00 & \\
\hline $11-20$ & 45 & 30.00 & \\
\hline $21-30$ & 19 & 12.67 & 14 persons \\
\hline $31-40$ & 5 & 3.34 & \\
\hline \multicolumn{4}{|l|}{ No of extension visits per year } \\
\hline $1-20$ & 72 & 48.00 & \\
\hline $21-40$ & 51 & 34.00 & \\
\hline & 27 & 18.00 & 29visits/yr \\
\hline \multicolumn{4}{|l|}{$\begin{array}{l}\text { No of social organizations } \\
\text { belonged }\end{array}$} \\
\hline None & 52 & 34.67 & \\
\hline $1-2$ & 75 & 50.00 & 1 social org. \\
\hline $3-\overline{4}$ & 22 & 14.67 & \\
\hline Above 4 & 1 & 0.67 & \\
\hline \multicolumn{4}{|l|}{ Annual income level (N) } \\
\hline Below N500,000 & 103 & 68.67 & \\
\hline $500,000-\mathrm{N} 100,0000$ & 45 & 30.00 & V326,461.30 \\
\hline Above 1000000 & 2 & 1.33 & \\
\hline
\end{tabular}


past 5 years $(\mathrm{N})$

None

$1,000-500,000$

$501,000-1,000,000$

Above 1,000,000

Land tenure system

Inherited

Purchased

Leased

Hired

Family/community
110

28

11

1

115

6

2

10

17
73.33

18.67

7.33

0.67

$\mathrm{N} 43,473$

Source: Field survey data, (2011)

\section{Sources of information on climate change}

Table 2 shows that majority (68\%) of the respondents relied on radio to get information on climate change, $38 \%$ used extension agents while $30 \%$ used television as source of information. It was observed that the use of other mass media sources like print media and the internet were poorly patronized with $0.67 \%$ and $2 \%$ respectively. This might be as a result of the low educational level of the respondents especially in the area of ICT. Nhemachen and Hassan (2007) noted that access to extension agents enhances adaptive capacity of farmers to climate change.

TABLE2

\section{Distribution of respondents based on sources of information on climate change ( $N=50)$}

\begin{tabular}{lll}
\hline Sources & Frequency & Percentage \\
\hline Radio & 102 & 68.00 \\
Television & 45 & 30.00 \\
Extension agents & 57 & 38.00 \\
Internet & 3 & 2.00 \\
Meteorological station & 9 & 6.00 \\
Fellow farmers & 14 & 9.33 \\
Cooperative societies & 9 & 6.33 \\
Religious bodies & 1 & 0.67 \\
Print media & 1 & 0.67
\end{tabular}

Multiple responses

Source: Field Survey data (2011) 


\section{Knowledge/perception of climate change by respondents}

Table 3 shows that the major indicators of climate change as perceived by the respondents include rising temperatures $(62.67 \%)$ erratic rainfall $(70 \%)$ and increased incidence of pests and diseases (32\%). This implies that the respondents were aware of climate change events in the area. Some of the climate change indicators identified by the respondents such as erratic rainfall and increased incidence of pests and diseases are capable of reducing farm yields and adding to the production cost. Increased pest and disease infestation could be as a result of increased rainfall intensity, high humidity and warmer environment. Farmers' knowledge of climate change indicators will help them adopt some adaptation measures.

TABLE 3

Distribution of respondents according to their knowledge and perception of climate change indicators $(n=150)$

\begin{tabular}{lll}
\hline $\begin{array}{l}\text { Indicators of climate } \\
\text { change }\end{array}$ & Frequency & Percentage \\
\hline High temperature & 94 & 62.67 \\
Erratic Rainfall & 105 & 70.00 \\
$\begin{array}{l}\text { Rising level of floods } \\
\text { Increase of pests and } \\
\text { disease }\end{array}$ & 7 & 48 \\
\hline
\end{tabular}

Multiple responses

Source: Field survey data (2011)

\section{Types of adaptation measures used by the respondents}

Table 4 shows the various adaptation measures practiced by the respondents. These include the practice of organic farming $(65.33 \%)$, use of resistant varieties $(53.33 \%)$, agroforestry practice $(52.67 \%)$, crop diversification $(48 \%)$ and early planting of crops (46.67\%), among others. These measures are aimed at maximizing yields and ensure food security. Crop diversification which implies growing a number of different crops in the same plot or in different plots reduces the risk of complete crop failure as different crops are affected differently by climate events. Nhemachena and Hassan (2007) reported that farmers are using crop management practices that include use of irrigation, water and soil conservation techniques and varying planting and harvesting dates to ensure that critical, sensitive growth stages that do not coincide with very harsh climatic conditions in the season. 
TABLE 4

Distribution of respondents according to types of adaptation measures used $(n=150)$

Multiple responses $\quad$ Source: Field survey data (2011)

\section{Factors militating against respondents' adaptive capacity}

Table 5 shows the mean distribution of respondents according to factors militating against their adaptive capacity to climate change. The factors which were perceived as serious constraints by the respondents (having means cores $>2$ ) include low income level, poor technological status, low level of education, poor access to information on climate change, unfavourable land tenure system, lack of government support, harsh economic policies, poor physical and social infrastructures in rural areas. These factors constitute bottleneck to any effort to adopt sustainable adaptation measure to climate change. Since most small scale farmers in the study area were low income earners and having little or no formal education, they lack the finance and other inputs to acquire the necessary adaptation measures to cope with climate change, especially those requiring huge capital investment and high technical skills. 
TABLE 5

Distribution of respondents according to factors militating against their adaptive capacity $(n=150)$

\begin{tabular}{lll}
\hline Factors & Total scores & $\begin{array}{l}\text { Means } \\
\text { scores }\end{array}$ \\
\hline Low income level & 388 & $2.59^{*}$ \\
Poor technology & 346 & $2.31^{*}$ \\
Low level of & 335 & $2.23^{*}$ \\
education & & \\
Inadequate & 329 & $2.19^{*}$ \\
information & & \\
$\begin{array}{l}\text { Poor extension } \\
\text { services }\end{array}$ & 290 & 1.93 \\
$\begin{array}{l}\text { Unfavourable land } \\
\text { tenure }\end{array}$ & 331 & $2.21^{*}$ \\
$\begin{array}{l}\text { No government } \\
\text { support }\end{array}$ & 354 & $2.36^{*}$ \\
\hline${ }^{*}=$ Serious constraint \\
to adaptation
\end{tabular}

\section{Determinants of adaptation measures to climate change}

The result of the regression analysis in table 6 shows that several characteristics of the respondents influenced either positively or negatively their adaptive capacity to climate change. Factors that were highly significant at $1 \%$ level include farming experiences, number of extension contacts per year, income level and type of land tenure system used. Factors that were significant at 10 percent were age, educational level, and amount of farm credit received.

The study revealed that age was negatively significant implying that older farmers had lower adaptive capacity than the younger once. Farming experience had positive significant implying that higher experience increases the probability of uptake of many adaptation measures. This implies that highly experienced farmers are likely to have more information and knowledge on changes in climatic conditions and crop and livestock management practices. Frequent contact with extension agents also increases the probability of taking up adaptation measures. This is because farmers who have significant extension contacts have better chances of to be aware of changing climatic conditions and management practices they can use to adapt to climate change. Similarly, income level showed significant effect implying that farmers with higher income levels were most likely to adopt adaptation measures than those with lower income level. The $\mathrm{R}$ square value of 0.544 implies that about $54 \%$ of the adaptive capacity of the respondents was determined by their socio-economic characteristics 
TABLE 6

Results of regression analysis on the effects of selected socioeconomic characteristics of the respondents on their adaptive capacity

\begin{tabular}{|c|c|c|c|c|c|}
\hline \multirow[t]{2}{*}{ Model } & \multicolumn{2}{|c|}{$\begin{array}{l}\text { Unstandardized } \\
\text { Coefficients }\end{array}$} & \multirow{2}{*}{$\begin{array}{l}\text { Standardized } \\
\text { Coefficients } \\
\text { Beta } \\
\end{array}$} & \multirow[t]{2}{*}{$\mathbf{T}$} & \multirow[t]{2}{*}{ Sig. } \\
\hline & B & Std. Error & & & \\
\hline Factor & 42.165 & 10.862 & & 3.882 & .000 \\
\hline Age in years & -.503 & .226 & -.239 & $-\overline{2}-227$ & $.028^{*}$ \\
\hline Sex of resp. & 5.712 & 5.023 & .070 & 1.137 & .257 \\
\hline Farm exp in years & .905 & .261 & .399 & 3.465 & $.001^{* * *}$ \\
\hline Years of schooling & -.580 & .323 & -.123 & $-\overline{1.797}$ & $.074^{\star}$ \\
\hline Farm size in hectares & -.027 & .273 & -.007 & -.099 & .921 \\
\hline $\begin{array}{l}\text { No. of persons in } \\
\text { household }\end{array}$ & -.103 & .222 & -.036 & -.463 & .644 \\
\hline $\begin{array}{l}\text { No. of extension } \\
\text { visit/year }\end{array}$ & -.145 & .028 & -.326 & - & $.000^{* * *}$ \\
\hline $\begin{array}{l}\text { No. of social } \\
\text { organizations }\end{array}$ & 1.333 & 1.489 & .060 & .895 & .372 \\
\hline Annual income in naira & $\begin{array}{l}2.99 \mathrm{E}- \\
005\end{array}$ & .000 & .354 & 5.184 & $.000^{* * *}$ \\
\hline $\begin{array}{l}\text { Amount of credit } \\
\text { received in naira }\end{array}$ & $\begin{array}{l}-2.66 \mathrm{E}- \\
005\end{array}$ & .000 & -.145 & $-\overline{2}-297$ & $.023^{*}$ \\
\hline Type of tenure system & -4.009 & 1.112 & -.228 & $-\overline{3.605}$ & $.000^{* * *}$ \\
\hline
\end{tabular}

\section{Conclusion and Recommendations}

The study sought to ascertain the perception/ knowledge of climate change and the agricultural adaptation strategies used by farmers in the southern agricultural zone of Nasarawa state. The results show that the mean age of the respondents was 48 years, majority (89.33\%) were males while the mean years of farming experience was 27 years. There was high level of extension contact among the respondents with a mean of 49 visits per year. The mean income level was N326, 461. 30 per annum and most $(76.67 \%)$ of the respondents used inherited farm lands. The major sources of information on climate change by the respondents were radio, extension agents and television. The respondents attributed the occurrence of erratic rainfall, excessive high temperatures and high incidence of pests and diseases to climate change events. Various adaptation measures were evolved by the respondents such as organic farming, use of resistant varieties, agroforestry practice, enterprise diversification and early planting of crops. Years 
of farming experience, number of extension visit per year, annual income level and type of land tenure system used were the major determinants of adaptive capacity to climate change. The factors considered as serious constraints to adaptation by respondents include inadequate finance, poor technology, low educational level, inadequate information, unfavourable land tenure as well as lack of government support.

It was therefore recommended that extension should brace up to the new challenges posed by climate change by retraining its staff, mounting awareness programmes, and disseminating proven technologies to boost the adaptive/ resilience capacities of various rural farmers to climate change. The government should provide agricultural loans and subsidies to small scale farmers to cope with the effects/impacts of climate change. Also, there is need for increased research and innovation in agriculture to find out more sustainable ways of adaptation to climate change.

\section{References}

Adger, W.N.; Huq, S.; Brown, K.; Conway, D. and Hulme, M. (2003). Adaptation to climate change in the developing world. Progress in Development Studies 3: 179-195.

Agwu, E.A.; Egbule, C.L., Amadu, F.O.; Morlai, T.A.; Wollor, E.T. and Cegbe, L.W. (2011). What policy options can promote agricultural innovations for climate change adaptation and food security in the West African Sub-region? African Technology Policy Studies Network. Technology Brief No.29. www.atpsnet.org.

Bradshaw, B.; Dolan, H., and Smith, B. (2004). Farm-level adaptation to climatic variability and change: Crop diversification in the Canadian Prairies. Climatic Change 67: 119-141.

Edwards P. G. and Clark, M. (2001). Changing the atmosphere: Expert Knowledge and Environmental Governance. Cambridge mass: MIT press.

IPCC (2001). Climate Change 2001: Impacts, adaptation, and vulnerability. Intergovernmental panel on climate change Cambridge, UK: Cambridge University Press

IPCC (2007). Climate change 2007: Synthesis Report. Contribution of working Group I, II and III to the fourth assessment report of the Intergovernmental panel on climate change. IPCC. Cambridge University Press, London.

Jones, J.W. (2003). Agricultural responses to climate variability and climate change. Paper presented at Climate Adaptation.net conference. Insights and Tools for Adaptation: Learning from climate variability. November18-20, 2003. Washington, DC. 
Nhemachena, C. and Hassana, R. (2007). Micro-level analysis of farmers adaptation to climate change in Southern Africa. IFPRI Discussion paper 00714 August, 2007. International Food Policy Research Institute, Washington, DC, USA.

Shrotriya, G. C. and Prakash, D. (2010). Climate Change Agricultural Cooperates. IFFCO Foundation, New Delhi, India.

Zoellick, R.B. (2009). A climate smart future. The Nation Newspaper. Vintage Press Ltd. Lagos, Nigeria. P18. 